\title{
Relative shrinkage of adipocytes by paraffin in proportion to plastic in human adipose tissue before and after weight loss
}

Citation for published version (APA):

Verhoef, S., van Dijk, P., \& Westerterp, K. R. (2013). Relative shrinkage of adipocytes by paraffin in proportion to plastic in human adipose tissue before and after weight loss. Obesity Research \& Clinical Practice, 7(1), e1-e88. https://doi.org/10.1016/j.orcp.2012.03.001

Document status and date:

Published: 01/01/2013

DOI:

10.1016/j.orcp.2012.03.001

Document Version:

Publisher's PDF, also known as Version of record

\section{Document license:}

Taverne

Please check the document version of this publication:

- A submitted manuscript is the version of the article upon submission and before peer-review. There can be important differences between the submitted version and the official published version of record.

People interested in the research are advised to contact the author for the final version of the publication, or visit the DOI to the publisher's website.

- The final author version and the galley proof are versions of the publication after peer review.

- The final published version features the final layout of the paper including the volume, issue and page numbers.

Link to publication

\footnotetext{
General rights rights.

- You may freely distribute the URL identifying the publication in the public portal. please follow below link for the End User Agreement:

www.umlib.nl/taverne-license

Take down policy

If you believe that this document breaches copyright please contact us at:

repository@maastrichtuniversity.nl

providing details and we will investigate your claim.
}

Copyright and moral rights for the publications made accessible in the public portal are retained by the authors and/or other copyright owners and it is a condition of accessing publications that users recognise and abide by the legal requirements associated with these

- Users may download and print one copy of any publication from the public portal for the purpose of private study or research.

- You may not further distribute the material or use it for any profit-making activity or commercial gain

If the publication is distributed under the terms of Article $25 \mathrm{fa}$ of the Dutch Copyright Act, indicated by the "Taverne" license above, 


\title{
Relative shrinkage of adipocytes by paraffin in proportion to plastic embedding in human adipose tissue before and after weight loss
}

\author{
Sanne P.M. Verhoef ${ }^{a, *}$, Paul van Dijk ${ }^{b}$, Klaas R. Westerterp ${ }^{a}$
}

\author{
a Maastricht University, Department of Human Biology, Nutrition and Toxicology Research Institute \\ Maastricht, 6200 MD, Maastricht, The Netherlands \\ ${ }^{\mathrm{b}}$ Maastricht University, Department of Anatomy and Embryology, Nutrition and Toxicology Research \\ Institute Maastricht, 6200 MD, Maastricht, The Netherlands
}

Received 12 January 2012; received in revised form 12 March 2012; accepted 12 March 2012

\section{KEYWORDS \\ Adipocytes; \\ Cell size; \\ Paraffin; \\ Technovit 8100}

\begin{abstract}
Summary Adipocyte size is a major modulator of endocrine functioning of adipose tissue and methods allowing accurate determination of adipocyte size are important to study energy metabolism. The aim of this study was to assess the relative shrinkage of adipocytes before and after weight loss by comparing adipose tissue from the same subjects embedded in paraffin and plastic. 18 healthy subjects ( 5 males and 13 females) aged $20-50$ y with a BMI of $28-38 \mathrm{~kg} / \mathrm{m}^{2}$ followed a very low energy diet for 8 weeks. Adipose tissue biopsies were taken prior to and after weight loss and were processed for paraffin and plastic sections. Parameters of adipocyte size were determined with computer image analysis. Mean adipocyte size was smaller in paraffin compared to plastic embedded tissue both before (66 \pm 4 vs. $103 \pm 5 \mu \mathrm{m}$, $P<0.001)$ as after weight loss $(62 \pm 4$ vs. $91 \pm 5 \mu \mathrm{m}, P<0.001)$. Relative shrinkage of adipocytes in paraffin embedded tissue in proportion to plastic embedded tissue was not significantly different before and after weight loss (73 and 69\%, respectively). Shrinkage due to the type of embedding of the adipose tissue can be ignored when comparing before and after weight loss. Plastic embedding of adipose tissue provides more accurate and sensitive results.

(C) 2012 Asian Oceanian Association for the Study of Obesity. Published by Elsevier Ltd. All rights reserved.
\end{abstract}

\footnotetext{
* Corresponding author. Tel.: +31 43 3881617; fax: +31433670976.

E-mail address: s.verhoef@maastrichtuniversity.nl (S.P.M. Verhoef).
}

\section{Introduction}

A major function of adipose tissue is storage and release of energy. Additionally, adipose tissue functions as an endocrine organ regulating energy expenditure, food intake and glucose metabolism. 
The extent of regulation, through secretion of hormones by the adipocytes, depends on the adipocyte size. Accordingly, adipocyte hypertrophy, a characteristic of obesity, leads to functional changes like increased inflammation and is hypothesized to thereby cause insulin resistance $[1,2]$. Therefore, it is important to determine adipocyte size and that methods used are accurate.

Many methods are described for determining adipocyte size, each with its advantages and disadvantages [3]. Measurements of triglyceride content per DNA content of adipose tissue as an estimation for adipocyte size is a relatively easy method, although prone to underestimation since DNA content also reflects other cell types. Another technique is fixation in osmium tetroxide combined with direct electronically counting of adipocyte number. Dividing lipid weight of a comparable sample by the electronically determined cell number is used to calculate mean adipocyte size. Disadvantages of this technique are the toxicity of osmium tetroxide and the overestimation of cell size due to the cell swelling caused by osmium. These methods also do not provide information on adipocyte size distribution. In contrast, collagenase treatment does separate adipocytes from stromal-vascular cells and followed by microscopic determination of cell size, adipocyte size distribution can be determined. One major disadvantage of this method is that large adipocytes break by the treatment, leading to underestimation of cell size. Measurements should be performed immediately after the collagenase treatment, because the cells cannot be stored without affecting cell morphology. On the contrary, fixed histological sections can be stored until analysis and cell size distribution is maintained.

Beside the techniques used to process the tissue, the method of measuring cell size is also important. Manually measuring adipocyte size is a tedious and time-consuming process. In contrast, computerized determination of adipocyte size allows measuring a large number of adipocytes in a rapid and reliable manner. Introducing a minimum and maximum value, below and above which cells are excluded from the analysis, prevents inclusion of artifacts. In addition, such cut off points help to exclude other cell types, like pre-adipocytes, from the analysis.

Fixation, embedding and cutting cause shrinkage and compression of the tissue. Paraffin is commonly used as embedding, whereas plastic embedding allows cutting thinner sections and gives better support to the cellular components, thereby improving morphology and minimizing cell shrinking. Shrinkage in paraffin-embedded tissue from various organs was reported to be $10-50 \%$, while shrinkage in plastic-embedded tissues was reported to range from 3 to $13 \%$ [4-6]. Especially adipose tissue is susceptible to cell shrinking because of the large lipid droplet comprising the largest part of adipocytes. This high lipid content in adipose tissue also results in a strong anti-freeze feature, and consequently we were unsuccessful in preparing cryostat sections from our human adipose tissue samples. In the present study, paraffin and plastic (Technovit 8100) embedded human adipose tissue derived prior to and after weight loss were compared to assess relative shrinkage of adipocytes.

\section{Materials and methods}

\section{Subjects}

Subjects were 4 males and 9 females aged $20-50$ y with a BMI of $28-38 \mathrm{~kg} / \mathrm{m}^{2}$, who participated in a weight loss study. The weight loss diet consisted of 8 weeks very low energy diet providing $2.1 \mathrm{MJ} /$ day (Modifast; Nutrition et Santé Benelux, Breda, The Netherlands). Biopsies were taken and body weight was determined at rest and following an overnight fast, both before and after weight loss. The study was conducted according to the guidelines laid down in the Declaration of Helsinki and procedures involving human subjects were approved by the Central Committee on Human Research and by the Medical Ethical Committee of the Maastricht University. Written informed consent was obtained from all subjects.

\section{Biopsy}

An abdominal subcutaneous adipose tissue sample was obtained by needle aspiration under local anaesthesia (2\% lidocaine). Samples were rinsed in sterile cold saline and stored in $4 \%$ formaldehyde. Part of the sample was dehydrated and embedded in paraffin, the other part of the sample was dehydrated with $100 \%$ acetone and embedded in Technovit 8100 (Heraeus Kulzer GmbH, Germany). Sections of $5 \mu \mathrm{m}$ were cut and stained with hematoxylin and eosin.

\section{Image analysis}

The sections were viewed with a Leica DMRE microscope, objective $20 \times$, Leica camera DC500 and images were obtained with Leica Image Manager (IM50), version 1.20 (Leica Microsystems AG, Switzerland). An image analysis computer programme (Leica QWin V3) was used to determine diameter $(\mu \mathrm{m})$ and area $\left(\mu \mathrm{m}^{2}\right)$ of the adipocytes 


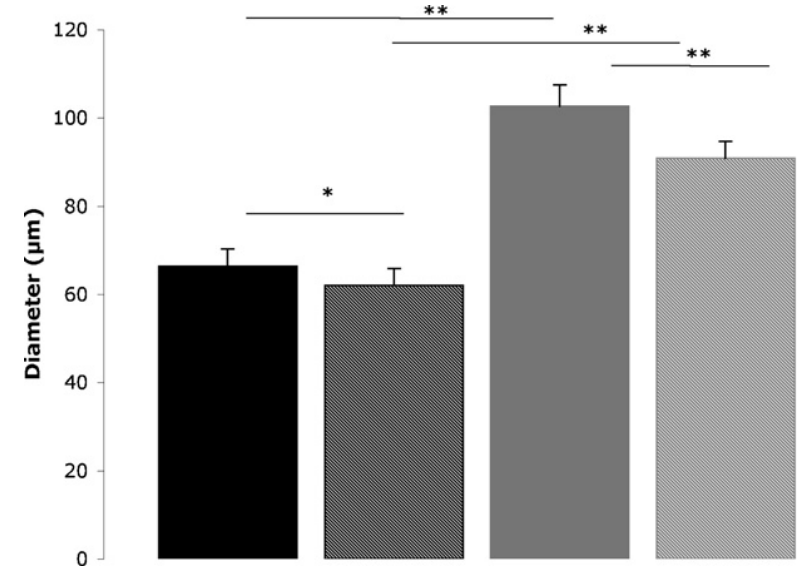

Figure 1 Mean $( \pm \mathrm{SD})$ adipocyte diameter $(\mu \mathrm{m})$ both pre (solid) and post (dashed) weight loss in paraffin (black) and plastic (grey) embedded tissue. Significant differences; ${ }^{*} P<0.01,{ }^{* *} P<0.001$ (paired $t$-test).

based on the method of Chen and Farese [3]. Results were directly loaded into a spreadsheet program (Excel; Microsoft Inc.) for analysis. Diameters $<40 \mu \mathrm{m}$ were assumed to represent artifacts or types of cells other than adipocytes and were excluded from analysis. Further analyses were done on results per subject. Adipocyte volume was calculated with the Goldrick formula [7]. Relative shrinkage of paraffin-embedded tissue in relation to plastic-embedded tissue was estimated by: 1 - (volume paraffin $_{\text {/volume }}$ plastic). A minimum of 250 cells was measured per subject per time point.

\section{Statistical analysis}

Data are presented as mean with the standard deviations, unless otherwise indicated. A paired $t$-test (two-tailed distribution) was carried out to determine possible differences between mean values. All frequency distributions were normally distributed. Significance was defined as $P<0.05$. All of the statistical analyses were executed with SPSS version 16.0 for Macintosh OS X (SPSS Inc., Chicago, IL).

\section{Results}

After weight loss mean adipocyte diameter and area were decreased in both paraffin and plastic embedded tissues (Fig. 1). This is visualized by a shift in the frequency distribution of the adipocyte diameter for both paraffin and plastic embedded tissue (Fig. 2). Comparing paraffin and plastic, mean adipocyte diameter $\quad(66 \pm 4$ vs. $103 \pm 5 \mu \mathrm{m}, \quad P<0.001$ before weight loss and $62 \pm 4$ vs. $91 \pm 5 \mu \mathrm{m}$,

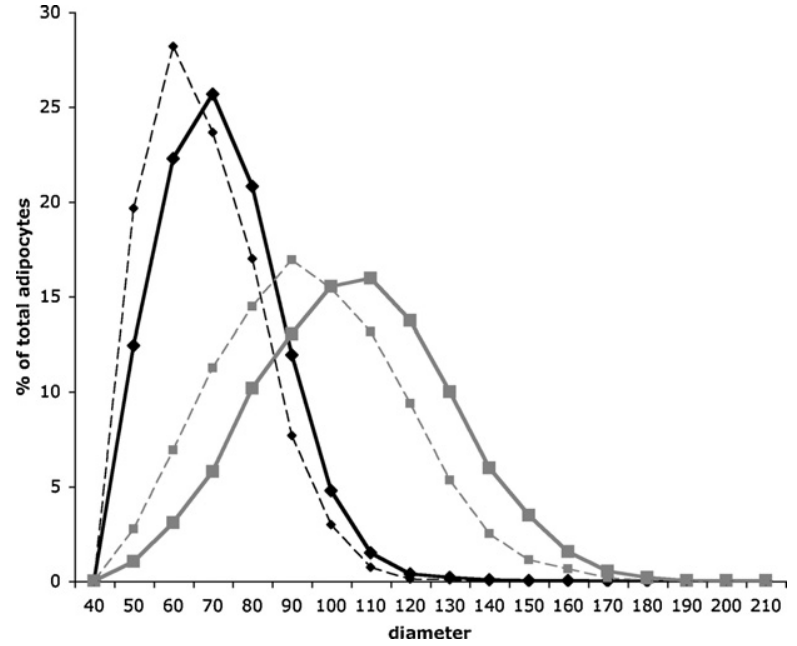

Figure 2 Frequency distribution of adipocyte diameter $(\mu \mathrm{m})$ both pre (solid) and post (dashed) weight loss in paraffin (black) and plastic (grey) embedded tissue.

$P<0.001$ after weight loss), area $(3621 \pm 434$ vs. $8746 \pm 802 \mu \mathrm{m}^{2}, P<0.001$ before weight loss and $3160 \pm 401$ vs. $6883 \pm 832 \mu \mathrm{m}^{2}, \quad P<0.001$ after weight loss) and volume $(174,990 \pm 31,505$ vs. $662,751 \pm 90,039 \mu \mathrm{m}^{3}, P<0.001$ before weight loss and $142,625 \pm 27,657$ vs. $466,669 \pm 87,273 \mu \mathrm{m}^{3}$, $P<0.001$ after weight loss) were smaller in paraffin embedded tissue both before and after weight loss. Hence, adipocytes shrink due to weight loss as well as embedding, with paraffin causing more shrinkage. However, the percentage decrease in diameter and area due to weight loss was not significantly different in plastic compared to paraffin embedded tissue. In addition, relative shrinkage of adipocytes in paraffin embedded tissue in proportion to plastic embedded tissue was $0.73 \pm 0.05$ before weight loss and $0.69 \pm 0.05$ after weight loss (range 0.58-0.82) (Fig. 3). This difference was not statistically significant.

In plastic embedded tissue adipocytes were more round after weight loss $(2.00 \pm 0.10$ vs. $2.12 \pm 0.13$, $P<0.05$ ), but there was no difference in roundness in paraffin embedded tissue before and after weight loss. However, before weight loss adipocytes had a higher roundness in paraffin compared to plastic embedded tissue $(1.82 \pm 0.17$ vs. $2.12 \pm 0.13$, $P<0.01)$. Possibly due to cell shrinking the cell membrane loosens and the extracellular space increases, which results in rounder adipocytes. In plastic the original cell structure is more preserved and therefore shrinking due to weight loss might cause the change in roundness of adipocytes in plastic and not in paraffin embedded tissue. The difference in roundness between paraffin and plastic before weight loss is probably caused by cell 


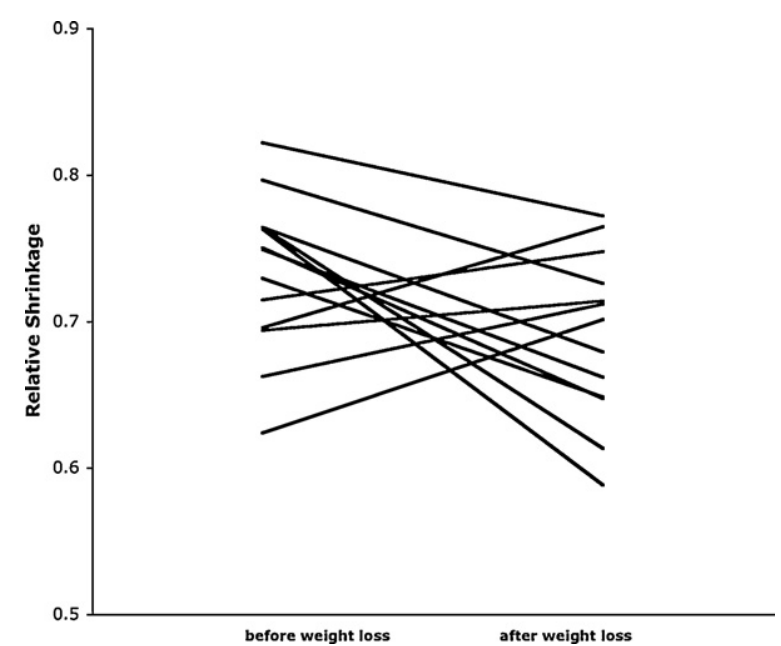

Figure 3 Relative shrinkage of adipose tissue in paraffin embedded tissue in proportion to plastic embedded tissue estimated by: 1 - (volume paraffin volume $\left._{\text {plastic }}\right)$.

shrinking due to paraffin embedding. After weight loss this difference in roundness did not reached significance $(P=0.09)$. Differences in overall morphology in plastic and paraffin embedded tissue can be seen in the microscopic pictures shown in Fig. 4.

\section{Discussion}

Adipocytes in paraffin embedded adipose tissue had a lower mean cell diameter and area before and after weight loss. Mean relative shrinkage of adipocytes in paraffin embedded tissue in proportion to plastic embedded tissue was 73 and $69 \%$ before and after weight loss, respectively.

Already in 1974 Fletcher compared plastic embedded avian tissues with the more conventional paraffin method and found that cell shrinkage was lower and fewer sectioning artifacts were present in plastic embedded tissue [8]. Recently, advantages of plastic embedding over paraffin in human bone tissue have been reported $[9,10]$. One disadvantage is that sectioning of plastic embedded tissue is more time consuming compared to paraffin. However, the advantages outweigh the disadvantages, since artifacts and cell shrinking do influence results that are based on morphological features.

The majority of studies using paraffin or plastic embedding to evaluate morphological characteristics of tissues do not include measurements of shrinkage. However, interpretation of quantitative parameters or density and size estimations may be very difficult without knowledge of the degree of shrinkage. Here, we defined relative shrinkage

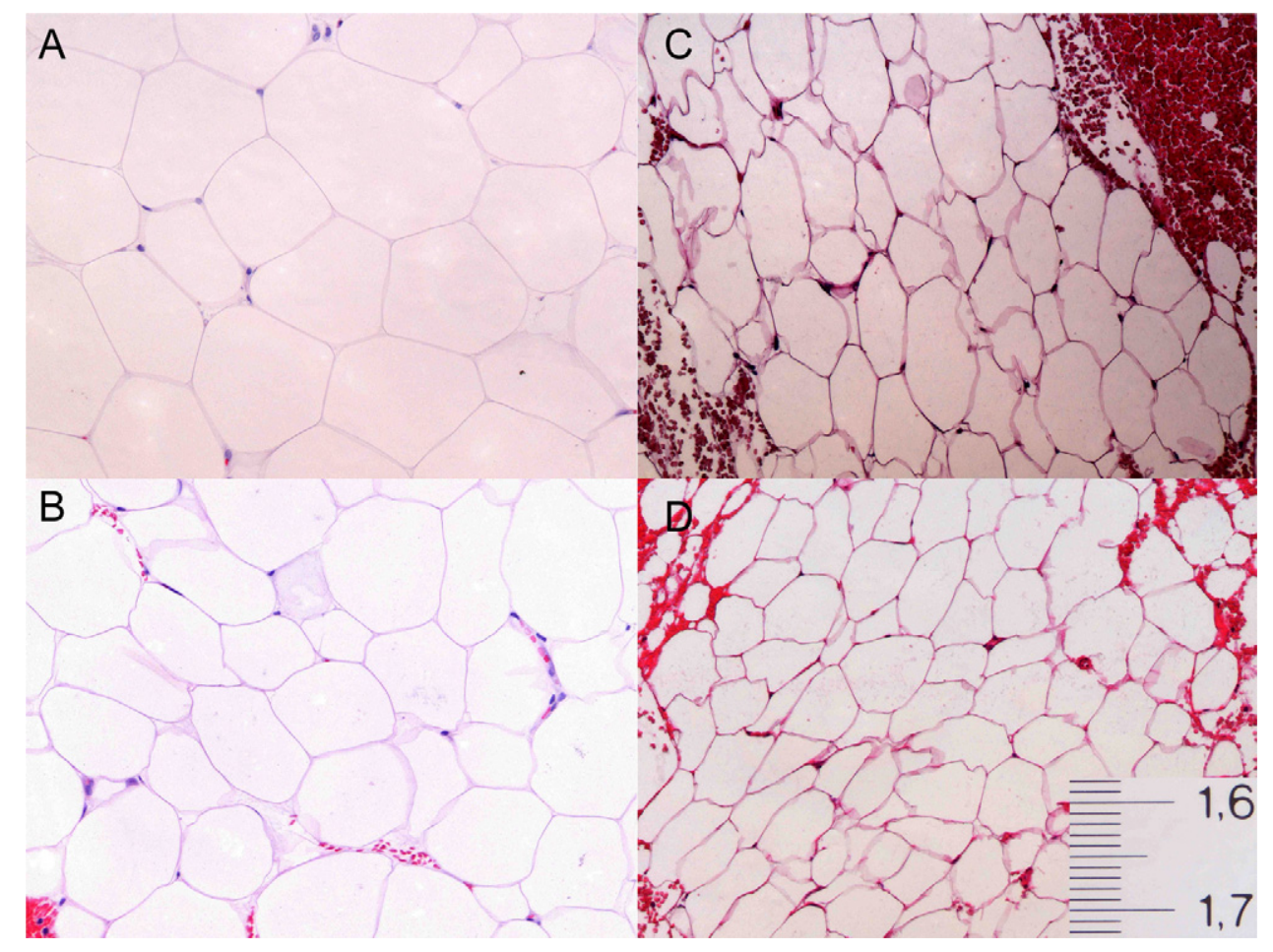

Figure 4 Microscopic picture of plastic $(A-B)$ and paraffin $(C-D)$ embedded adipose tissue before $(A-C)$ and after $(B-D)$ weight loss in one subject with a $20 \times$ magnification (scale in $\mathrm{mm}$ ). 
of paraffin embedded adipose tissue in proportion to plastic embedded adipose tissue, since plastic is suggested to virtually remove shrinkage [6]. Paraffin embedding caused a relative shrinkage of about $70 \%$ in proportion to plastic embedding. This is high compared to findings from other studies, which reported shrinkage from 10 to $50 \%$ in different organs [4-6]. The use of adipose tissue in this study probably caused this high relative shrinkage, since adipose tissue is susceptible to cell shrinking because of the large lipid droplet comprising the largest part of adipocytes. Although the high relative shrinkage, paraffin embedding produced consistent results in the different tissues. Relative shrinkage was not significantly different in adipose tissue before and after weight loss. Therefore, the shrinkage of adipose tissue due to embedding in this study can be ignored.

High cell shrinking due to paraffin embedding might have consequences for interpretation of results. The degree of cell shrinkage might be important for defining cut off points, in order to exclude cells other than adipocytes. Beside some studies that do not even take into account such cut off points [2,11-15], the values that are used as cut off point vary greatly $[16,17]$. In this study a diameter of $40 \mu \mathrm{m}$ was used as a cut off point for both paraffin and plastic embedded tissues. Since several methods of processing result in different degrees of cell shrinking, therefore the use of the same cut off points for different methods might be questioned. Another consequence of higher cell shrinking in paraffin embedded tissue is a lower sensitivity to detect significant differences in cell size measurements.

One explanation for the continuous use of paraffin embedded tissue is immunohistochemical staining, since the effectiveness largely depends on the type of fixation, preparation and embedding. The advantage of paraffin embedding for immunohistochemical staining is the lack of chemical interaction with the tissue. Recently, immunohistochemical staining of bone tissue embedded with Technovit 9100 New showed a stronger immunostaining for several markers and a better preservation of trabecular bone morphology compared to paraffin embedding $[9,10]$. Because of the continuous use of paraffin, most protocols for immunohistochemical staining are optimized for this type of embedding. However, when protocols would be optimized for plastic embedded tissues, the morphological advantages of this technique could also be exploited when immunohistological staining is required. One disadvantage is the higher costs associated with plastic embedding.
A limitation of our study is the small sample size of our population with both male and females and a relatively large variation in age and BMI. Age, BMI and sex could have an effect on adipocyte size. However, by comparing both techniques by defining relative shrinkage of paraffin-embedded tissue in relation to plastic-embedded tissue within the same subjects before and after weight loss, we believe that a possible effect of age, BMI and sex on adipocyte size would not influence our conclusion.

In conclusion, shrinkage of adipose tissue due to the type of embedding in this study can be ignored, since relative shrinkage was not significantly different in adipose tissue before and after weight loss. However, paraffin embedded tissue resulted in higher cell shrinkage and has the disadvantage of poorer morphology. Therefore, plastic embedding is more accurate and susceptible to detect differences in adipocyte size caused by weight loss.

\section{Conflict of interest}

None of the authors had any conflict of interest.

\section{Acknowledgements}

K.R. Westerterp and S.P.M. Verhoef designed the study. S.P.M. Verhoef collected and analyzed the data and wrote the manuscript. W.H. Lamers and K.R. Westerterp contributed to the interpretation of the data and reviewed the manuscript. The study was executed under supervision of K.R. Westerterp. Thanks to Paul van Dijk for his excellent assistance of histological methods, Jack Cleutjens for his assistance of the image analysis computer programme and Stefan Camps for his assistance in data collection. All authors read and approved the final manuscript.

\section{References}

[1] Gauthier MS, Ruderman NB. Adipose tissue inflammation and insulin resistance: all obese humans are not created equal. The Biochemical Journal 2010;430:e1-4.

[2] He ML, Sharma R, Mir PS, Okine E, Dodson MV. Feed withdrawal abate regimens lipodystrophy and metabolic syndrome symptoms, such as glucose tolerance, are associated with the diameter of retroperitoneal adipocytes in rats. Nutrition Research (New York, NY) 2010;30:125-33.

[3] Chen HC, Farese Jr RV. Determination of adipocyte size by computer image analysis. Journal of Lipid Research 2002;43:986-9.

[4] Hanstede JG, Gerrits PO. The effects of embedding in water-soluble plastics on the final dimensions of liver sections. Journal of Microscopy 1983;131:79-86. 
[5] Helander KG. Thickness variations within individual paraffin and glycol methacrylate sections. Journal of Microscopy 1983;132:223-7.

[6] Nielsen KK, Andersen CB, Kromann-Andersen B. A comparison between the effects of paraffin and plastic embedding of the normal and obstructed minipig detrusor muscle using the optical dissector. The Journal of Urology 1995;154:2170-3.

[7] Goldrick RB. Morphological changes in the adipocyte during fat deposition and mobilization. The American Journal of Physiology 1967;212:777-82.

[8] Fletcher OJ. Research note: plastic embedding of avian tissues for diagnostic histopathology. Avian Diseases 1975;19:201-8.

[9] Willbold E, Witte F. Histology and research at the hard tissue-implant interface using Technovit 9100 New embedding technique. Acta Biomaterialia 2010;6:4447-55.

[10] Wittenburg G, Volkel C, Mai R, Lauer G. Immunohistochemical comparison of differentiation markers on paraffin and plastic embedded human bone samples. Journal of Physiology and Pharmacology 2009;60(Suppl. 8):43-9.

[11] Bambace C, Telesca M, Zoico E, Sepe A, Olioso D, Rossi A, et al. Adiponectin gene expression and adipocyte diameter: a comparison between epicardial and subcutaneous adipose tissue in men. Cardiovascular Pathology 2010.
[12] Farnier C, Krief S, Blache M, Diot-Dupuy F, Mory G, Ferre $P$, et al. Adipocyte functions are modulated by cell size change: potential involvement of an integrin/ERK signalling pathway. International Journal of Obesity and Related Metabolic Disorders 2003;27:1178-86.

[13] Garaulet M, Hernandez-Morante JJ, Lujan J, Tebar FJ, Zamora S. Relationship between fat cell size and number and fatty acid composition in adipose tissue from different fat depots in overweight/obese humans. International Journal of Obesity (2005) 2006;30:899-905.

[14] Miyazaki S, Izawa T, Ogasawara JE, Sakurai T, Nomura S, Kizaki T, et al. Effect of exercise training on adipocytesize-dependent expression of leptin and adiponectin. Life Sciences 2010;86:691-8.

[15] Varady KA, Tussing L, Bhutani S, Braunschweig CL. Degree of weight loss required to improve adipokine concentrations and decrease fat cell size in severely obese women. Metabolism: Clinical and Experimental 2009;58:1096-101.

[16] DeMartinis FD, Francendese A. Very small fat cell populations: mammalian occurrence and effect of age. Journal of Lipid Research 1982;23:1107-20.

[17] Tchoukalova YD, Harteneck DA, Karwoski RA, Tarara J, Jensen MD. A quick, reliable, and automated method for fat cell sizing. Journal of Lipid Research 2003;44: 1795-801. 